Kazimierz Wielki University in Bydgoszcz

acichosz@o2.pl

\title{
THE BEGINNING AND DEVELOPMENT OF THE SOCIO-CULTURAL ANIMATION In Poland
}

\begin{abstract}
Socio-Cultural Animation is currently one of the most significant areas of educational activity discussed within social pedagogy. Among social work, tutelary work or health education, it is one of the most important areas of educational practice widely studied within social pedagogy and, consequently, transferred on the specific methodology of practical activities. Simultaneously, it is worthwhile to indicate the significance of the space which encompasses this practice - namely Culture. It is one of the most rudimentary areas influencing human upbringing process, their development and social activity.

Therefore, Socio-Cultural Animation is a very important and key area of pedagogical activity. At the same time, being a specific type of reflection, it has undergone and still undergoes the process of development. The reflection over the educational activity undertaken within and through culture, experienced various stages of its recognition. At the very beginning, when it appeared in the circle of interests of the social pedagogy forerunners, it was treated (in a specific sociopolitical context) as an area of educational activities with an important role of institutions which ought to undertake such activities under certain social conditions. The notion of animation was then associated with the concept of creative activity which has remained its constitutive feature as educational practice up to this point. The following years of reflections over socio-cultural animation maintained its more institutional and functional character, yet, it was more and more frequently connected and more clearly implemented with the notion of cultural education as
\end{abstract}


part of the pedagogy of culture. Currently there are various ways of understanding socio-cultural animation accepted by social pedagogy. One of them is the concept of environmental education which sees the area of culture as the important and desired space of realizing education.

KEYWORDS: culture, creativity, education, schooling, environment, environmental education, institution

\section{INTRODUCTION}

The area of culture is regarded as a field of human creative activity. This is a sphere of human creative struggles with himself and the others - the world outside and inside all of us. It is also an area of spiritual experiences - putting questions about the sense, the identity, the present, the future. However, this world - the world of culture is also the one we share and the one we invite others to, the one we hand down - it is the world of human educational activity. In the context of social sciences, this activity is often referred to as sociocultural animation. It has a rich tradition of undertaken solutions, accepted ideas and activity concepts. Therefore, worthwhile is the question of how that idea developed in the ground of pedagogy, especially social pedagogy which has worked out particular solutions in this area, indicating socio-cultural animation as one of its proper and specific areas.

\section{EDUCATIONAL-CULTURAL CURRENT}

Since the very beginnings of social pedagogy in Poland, the issues of culture and scholastic activities connected with it have been related to the notion of education ${ }^{1}$ understood as determined and broadly defined practices aimed at general upbringing and mostly of non-school character. This notion ought to be understood in a broader historical and social context especially with regards to the current of social pedagogy.

The term was coined when Poland was deprived of independence and this fact inspired the social thought and the arising social pedagogy at that times. The ideas of education and precisely its components like schooling and cultural work were primarily seen as drive for independence and, secondly, as reformatory aspirations. Aspirations, in which the cultural content played rudimental role, both built up the national awareness and served as a 
developmental factor the whole society and individuals. The creator of social pedagogy - Helena Radlińska wrote in one of her works:

...Education and upbringing are a social function. The right to be educated ought to be sought in life itself. The primary phenomenon of social life is the cultural development; the vocation of every human being is creation and improvement of national culture; the role of nations - implementing the cultural benefits in the life of humanity. Every work, every struggle to implement a given cultural idea in real life contributes to the development of humanity... (Radlińska, 1935, s. 10).

Such attitude, seen from various perspectives, was presented by the author in her further papers such as: Educational work, methods, tasks and organization or The study of cultural work and The education and culture of the Polish countryside. It may be stated that this notion became the systemic notion of her activity and was characteristic of the social pedagogy of that time.

It is important that in this educational-cultural current, Helena Radlińska took on a subjective, humanistic approach seeing a human being as a unit with certain capacities regarding its participation in culture. In the context of educational activities according to the presented vision of human being, another term was coined - creativity. The shaping of creative attitude was also supposed to be the effect of educational work both cultural and schooling. This notion has been the key idea of social-cultural animation since that point regardless of its interpretation.

Stanisław Korniłowicz, one of the forerunners of social pedagogy, also studied the phenomenon of cultural work and described it in the following way:

...The demand of creative democracy is not only to make the cultural values available for the masses but also to enable creative units of all social layers to participate in the shaping of culture, enabling various social groups to created their own cultural structures. In this respect there is an urgent need for a social action aimed to facilitate individuals and groups in the development of creative skills and talents. In other words, cooperation in the development of culture (science, art) through preparing workers and organizing workshops about cultural production. Such social activity, aimed at facilitating the creation of cultural values instead of simply spreading them, is defined as the creative function of cultural work... (Korniłowicz, 1976, s. 128). 
It may be observed that the notion of cultural work and educational work, or rather cultural work seen as an element of broader educational activity, was of more instrumental (in the sense of the need for undertaking specific action) and institutional character. Such an approach is supported by a relatively unknown project of Dissemination of cultural heritage and nonschool education act by Helena Radlińska published in one of her works. The author claims that:

...Making the cultural heritage available and propagating the participation in cultural creativity requires:

- tools capable of storing and distributing the heritage as well as bringing out interests...,

- common education that develops skills to use the cultural heritage and facilitates creative skills,

- supporting cultural activity in all areas of science and art, its devotion, work, social co-existence, spiritual and physical development of an individual,

Fulfilling of these tasks is possible with the cooperation of many institutions and undertakings. The success of cultural activity depends not only on the eminent creators and the attitude of people and groups which are the most active and the most aware but, to a greater extent, on breaking up with the passiveness of those who remained incapable of even participating in the reception of culture.

The organization of cultural work should enable the broadest possible participation, connection of various areas of culture, availability of tools, providing incentives, freedom of initiatives and professional help in their realization (Radlińska, 1947, s. 217).

Accepting such an approach, the early social pedagogists indicated the necessity to create numerous cultural-educational institutions where such cultural work would be undertaken. In the previously cited work edited by Stanisław Korniłowicz, Helena Pleszczyńska provides a rich collection of such institutions - frequently repeated and referred to, though modernised, by successive generations of social pedagogists. She enumerated the following:

- Lectures and cycles,

- Common university lectures, 
- Common regional universities,

- Common universities,

- Civic courses,

- Schools for adults and adolescents,

- Folk Agricultural Schools,

- Dormitory type folk universities,

- Sunday universities,

- Summer courses,

- Common libraries,

- Youth clubs,

- Youth associations,

- Community centres,

- Community Theatres,

- Musical activity,

- Radio,

- Museums, exhibitions,

- Sightseeing, trips, summer camps,

- Counselling services, instructional help, publishing companies, scientific research,

- Trainer courses and conventions of educators,

- The Study of Social-Educational Work at the Free Polish Universit ${ }^{2}$ Polish: Wolna Wszechnica Polska (Konewka, Korniłowicz, 1929, s. 58-79).

At the same time it is worthwhile that these institutions have been regarded as educational environment from the very beginning and, as such, have been the area of social-pedagogical research as the place where every educational tasks and activities occur. Therefore it was a wide ontological and epistemological perspective of this new and constantly shaping pedagogical discipline. With regards to these issues, the deliberations of Zofia DaszyńskaGolińska $^{3}$ seem especially interesting. It was already in 1913, when she wrote about Community Centre (named a Folk House at that time) as a typical educational institution related to cultural work and pointed out the requirements and conditions it has to fulfil in order to become educational environment; 
...In order to become live environment a Folk House ought to:

fulfil free-time needs of all age categories through:

- arousing mental development of the participants,

- dissemination of artistic culture,

- spreading patterns of "civilised", "versatile" and "free" relax and entertainment,

- developing sport and physical education and facilitating sport events,

- stimulating "internal ethical unity" of the participants,

- arousing needs of "higher moral life",

- running prophylactic activities against deviation,

- making the Folk House a central point which gathers all kinds of associations and clubs... (Borowski, Daszyńska-Golińska, 1913, s. 372-378).

Setting the notion of culture mainly in the area of education - educational and cultural work was a clear sign of practical or even praxeological tendency and distinct institutionalism.

At the same time it is noteworthy that the social pedagogists of that period did not expand the concept of culture itself. Such deep analyses are hard to find in that period of shaping of social pedagogy. Researchers mainly based on the assumptions and claims accepted by sociology of education typical of that time. Such literature was the richest source of reference for H. Radlińska as well as other representatives of this discipline. Whether directly or indirectly, they most often drew their knowledge from the field of social politics which in that time expressed a clear practical, institutional and reformatory orientation (e.g. in: L. Krzywicki, K. Krzeczkowski or St. Rychliński).

The notion of educational and cultural work remained in such a shape in social pedagogy until post-war period when a new chapter of understanding opened.

\section{SYSTEMIC CURRENT - CULTURAL-EDUCATIONAL} ACTIVITY

The new approach saw education mainly as an effect of social activity, planned and fully realized within a holistically organized system of educational influences. The integrity of the system was ensured by the ideology of socialistic education accepted at that times. 
Despite significant changes which occurred in social pedagogy of that period - especially with respect to ideological rudiments, the notion of educational activities with regards to culture was still perceived to be mainly realized out of schools. It was also believed to involve mainly adults (yet not only). It was also eminent that these activities were associated with the area of free time. At that time, Aleksander Kamiński wrote that:

...We could also say that culture is a sphere of human life and activities developing in the free time and having no direct utilitarian character... (Cichosz, 2006, s. 151).

Such thread hardly occurred, or was not so strongly stressed, in the parallel works of another significant figure of post-war social pedagogy - Ryszard Wroczyński. The author wove it into the issues of non-school education.

Following the route of social pedagogists of those times, including A. Kamiński, and other authors representative of that period of shaping of the discipline (yet inspired earlier) - the culture itself was regarded as a set of values, norms, patterns and models. Adopting the contemporary, elaborated goal of all activities suggested in social pedagogy, aimed at organizing environment regardless of the theoretical and methodological context, the following issues were indicated with respect to culture:

- making culture available,

- disseminating culture,

- introducing in culture.

These were the layers on which the scope of necessary activities within culture were established. That was the basic layer of recognising culture according to which various concepts were accepted both in terms of the assumed theoretical settlements and suggested practical solutions. It lead to a certain isolation of a separate branch of social pedagogy - the branch of environmental practice, which was then described as: cultural-educational activity (derived from the stylistics of: educational and cultural work). The clear practical character of cultural activities and the institutionalism of the adopted solutions with regards to educational practice were strongly consolidated at that time. Among the key and principal works for such an understanding of cultural-educational activity is the paper entitled The basics of educationalcultural activity (Jankowski, Kargul, Kowalski, Przyszczypkowski, 1985). 
Such way of understanding was supported by the contemporary systemic and functional approach to the issues of education. A number of works related to the area of cultural-educational activity were created. Most of them expressed a highly methodological character describing the institutions of culture and characterising them in terms of their expected functions, the role of an educator, pedagogist, animator and other issues significant to the functioning of such activity (Dobrzyński, 1975; Kałużny, 1973; Olszewski, 1965; Kargul, 1976; Jankowski, 1977). Important figures - authors of this area were Józef Kargul, Anna Przecławska, Jan Żebrowski and Dzierżymir Jankowski.

These authors brought up significant theoretical and practical issues connected with cultural-educational activity.

Dzierżymir Jankowski defined the activity as: ... a system of organized, freetime cultural activities of children, adolescents and adults of creative character... (Jankowski, Kargul, Kowalski, Przyszczypkowski, 1985, s. 11).

This perspective continues the earlier elaborated tradition in social pedagogy and sees cultural-educational activity as a method of environmental work. In this respect, the following methods of environmental work were quoted in order to satisfy the needs of activities within culture: individual cases method, group work method, environment organization method. One of the first researchers who followed this thread in the literature related to social pedagogy was Olga Czerniawska.

The systemic character of such environmental work and the need for its planning and programming was constantly emphasized to be the part of the holistic system of educational influences. The whole-life space was indicated as the most adequate and proper area for such influences and, as such, was included in the concepts of continuous education.

\section{THE CURRENT OF CULTURAL EDUCATION AND ENVIRONMENTAL EDUCATION}

At the beginning of the 1990's after the systemic transformation and after turning down the previous ideological models in social sciences, including pedagogy, the described pattern of cultural-educational activity also underwent verification. 
With regards to these changes Polish pedagogy gained access to previously unavailable western literature regarding the notion of creative activity within or through culture - named as Socio-Cultural Animation.

Such a concept had been known in Polish literature. In the 1970's and 80's, based on western models, O. Czerniawska wrote about this kind of educational work, however, it had been merely known and was not adopted for the contemporary settlements in the grounds of Polish pedagogy (due to ideological dissimilarity). The key work of that period was the work by Małgorzata Kopczyńska entitled Socio-Cultural Animation (Kopczyńska, 1993).

This new approach to understanding educational activity within culture - Socio-Cultural Animation, emphasized the importance of arousing and facilitating creative activity of a subject especially in the field of culture but also stimulating their social activity. Therefore this approach promoted social integration and participation as the aim of socio-cultural animation.

In the literature of the subject shall be made of the various divisions of the socio-cultural animation features that indicate objectives. Barbara Jedlewska said here about the features; adaptive, participatory communication, integration and education (Jedlewska, 1995). Such practical understanding of animation - as indicated by its features - allows to define it as a method of action. And here indicates that the range of this method, as the action in the work of the cultural and socio-educational activities in education (to stimulate, assist, wake up the joy to create, curosity, wake up the motivation and faith in its own strength), the dissemination of education and culture.

In the narrow terms of the socio-cultural animation, defined as a method of action, stands out her specific techniques. Most shows on techniques such as: organizational technology - related closely to the promotion and dissemination of cultural activities with the methodology of the events and the work of institutions, dissemination of culture; communication techniques - these are the theatre techniques strictly, such as adequate broadcast voice and director events; group work techniques - in terms of the form of action in the group; techniques associated with the activities of thrives - training, participatory, playing (achieving relaxation, leisure activities, satisfaction from participation in the game), are listed here also; festivals, games, tourism, sport activity (Zierkiewicz, 2006). 
The presented inspiration of western pedagogy for the Animation (i.a. with regards to the way of understanding human and its role in the social life as well as the tasks of education) is clearly located in the critical-creative current which is different from the previous adaptative approaches which emphasized the institutional and functional character of such activities.

Such inspirations were also an incentive for modern current within Socio-Cultural Animation which is Cultural Education applied mainly in the context of the Pedagogy of Culture in the broad sense which focused on such goals like:

- restoration and protection of cultural heritage,

- creating conditions for cultural and artistic activity,

- expanding active participation in cultural life... (Jedlewska, 1999).

Particular highlights for animation socio-cultural issue of the cultural heritage. In spite of the fact to the animation, which is integrating community and building community this objective can't level out the cultural differences - is a national, that are the wealth of each community. Leon Dyczewski writes: ... a particularly important for Europe cultural group is the nation [...]. Emphasizing the cultural sovereignty of each ethnic group and every people in Europe is not a manifestation of separatism or nationalism, but understanding the essence of cultural riches, because all cultures are part of the common heritage of humanity (Dyczewski, 1995). To carry out these tasks, the author asserts, also in the animation activities following principles; love and sense of the validity of their own culture; dialogue with other cultures; an attitude of respect for other cultures; exchange and contribute in place of dominance.

The indicated relationship between socio-cultural animation and the pedagogy of culture visible both in literature and educational practice is worth further exploration as it is a specific relationship which stems from a certain tradition in the Polish pedagogy including the context of esthetical education.

At the same time, continuing the social pedagogy tradition and its understanding of socio-cultural animation as well as motivated by western pedagogy, developed the current of the so called Environmental Education. 
It accentuated the need for social and environmental influence on the participants of social life aimed at facilitating their activity and creativity with regards to various layers of human social participation, also in culture [displaying strong and visible signs of the idea of social enforcement - empowering].

According to Wiesław Theiss, such education is defined as:

...Informal education of children, adolescents and adults connected with the realization of the needs of environment or local community.

Its aim is:

- finding, apprising and developing of local socio-cultural resources and hence shaping local identity...

- Shapingactive and creativeattitudes of individuals, groups andlocal communities in the construction of human micro-world... (Theiss, 1996, s. 12).

To sum up, it may be said that Socio-Cultural Animation, finally understood as determined educational activity aimed to facilitate creative activity and social participation may be realized in terms of Cultural Education and Environmental Education. The former stems from the area of the Pedagogy of Culture, the latter is an evident continuation of the routes and tradition of Social Pedagogy.

Seeking the understanding of the mentioned relationships and considering the development of concepts regarding this field, one may observe other inspirations concerning educational practice, also coming from other sciences. Nevertheless, with regards to Socio-Cultural Animation the two described paths seem especially clear and leading.

Apart from the need for exploring and reconstructing the sources of Socio-Cultural Animation which allows for determining its nature and how it gained its identity, always current remains the problem of the challenges of the present times. It deals with the issue of transformations of modern culture - its nature and changes it undergoes, but also the problems it brings about for those who undertake and will undertake animation-educational activities. Therefore it is another field for analyses necessary for modern theory and practice of socio-cultural animation. 


\section{References}

Badura, J., Czerniawska, O. (1979). Instytucje i placówki kulturalno-wychowawcze, Warszawa: Instytut Wydawniczy CRZZ [Centralnej Rady Związków Zawodowych].

Borowski, T., Daszyńska-Golińska, Z., Dziubińska, J., Gargasa, Z., Heilperna, M., Kruszewska, Z., Krzywicki, L., Orsetti, M., Orsza, H., Posner, S., Stępowski, M., Szydłowski, T., Weychert-Szymanowska, Wł. (1913). Praca oświatowa, jej zadania, metody, organizacja, Kraków: Michał Arct.

Cichosz, M. (2004). Polska pedagogika w latach 1945-2003, tom II, Toruń: Wydawnictwo Adam Marszałek. ISBN 8373228209.

Dobrzyński, K. (1975). Wychowanie w działalności kulturalno-oświatowej, Warszawa: Instytut Wydawniczy CRZZ.

Dyczewski, L. (1995). Kultura polska w procesie przemian, Lublin: Towarzystwo Naukowe Katolickiego Uniwersytetu Lubelskiego. ISBN 8385291636.

Jankowski, D., Kargul, J., Kowalski, F., Przyszczypkowska, K. (1985). Podstawy działalności kulturalno-oświatowej, Warszawa: Centralny Ośrodek Metodyki Upowszechniania Kultury. ISBN 8320904803.

Jankowski, D. (1977). Dom kultury, Warszawa: Centralny Ośrodek Metodyki Upowszechniania Kultury. ISBN 9788320904802.

Jedlewska, B. (1999). Animatorzy kultury wobec wyzwań edukacyjnych, Lublin: Wydawnictwo UMCS. ISBN 9788322714669.

Kałużny, Cz. (1973). Zasady, metody, formy działalności kulturalno-oświatowej, Warszawa: Instytut Wydawniczy CRZZ.

Kargul, J. (1976). Pracownik kulturalno-oświatowy, Warszawa: Instytut Wydawniczy CRZZ. ISBN 9788362015313.

Konewka, A., Korniłowicz, K. (1929). Przewodnik oświaty dorostych (1928), Warszawa: Wydawnictwo Federacji Oświatowej Organizacji Społecznych.

Kopczyńska, M. (1993). Animacja społeczno-kulturalna, Warszawa: Centrum Animacji Kulturalnej. ISBN 8370101097.

Korniłowicz, K. (1976). Pomoc społeczno-kulturalna dla młodzieży pracującej i dorostych. Wybór Pism, wstęp, wybór i opracowanie O. Czerniawska, Wrocław-Warszawa-Kraków: Ossolineum.

Olszewski, H. (1965). Organizacja pracy kulturalno-oświatowej, Warszawa: Instytut Wydawniczy CRZZ. 
Radlińska, H. (1925). Studium pracy kulturalnej, Warszawa: Nasza Księgarnia.

Radlińska, H. (1935). Stosunek wychowawcy do środowiska społecznego. Szkice z pedagogiki społecznej, Warszawa: Nasza Księgarnia.

Radlińska, H. (1947). Oświata dorostych, Warszawa: Ludowy Instytut Oświaty i Kultury.

Radlińska, H. (1979). Oświata i kultura wsi polskiej, Warszawa: Ludowa Spółdzielnia Wydawnicza.

Theiss, W. (1996). Edukacja środowiskowa. Zarys problematyki, „Problemy Opiekuńczo-Wychowawcze", 10. ISSN 0552-2188.

Zierkiewicz, E. (2006). Tworzyć, zmieniać, aktywizować, Wrocław: Mar-Mar. ISBN 9788387196974.

\section{Endnotes}

1 Translator's note: The Polish term - oświata slightly differs from education as education is simply connected with schooling whereas oświata expresses a broader and deeper activities meant to enlighten the nation and develop knowledge, culture and proper behaviour rather than simply teaching.

2 Translator's note: Polish - Wolna Wszechnica Polska.

${ }^{3}$ Zofia Daszyńska-Golińska is still not widely recognizable figure. She is numbered among the forerunners of social pedagogy. She is also a qualified economist, social activist engaged in politics around socialistic parties. She received the $\mathrm{PhD}$ title at the University of Zurich. She worked at the Humboldt University in Berlin and was connected with Adam Mickiewicz common University in Kraków. Since 1919 worked as a professor at the Free Polish University; cooperated with H. Radlińska. 
